\title{
Effectiveness of Cordyceps sp. and Beauveria bassiana against large cabbage-heart caterpillar, Crocidolomia pavonana Fabricius (Lepidoptera: Crambidae)
}

\author{
Agus Dana Permana $^{1 *}$, Sally Marlinda ${ }^{1}$, Agus Susanto ${ }^{2}$, Amin Setyo Leksono $^{3}$ \\ ${ }^{1}$ School of Life Sciences and Technology - Institut Teknologi Bandung. \\ J1. Ganesha No. 10 Bandung 40132, Indonesia. Phone: +62222500258; Fax. +62222534107. \\ ${ }^{2}$ Department of Pest and Plant Disease, Faculty of Agriculture, \\ Universitas Padjadjaran, Jatinangor, 45363, Indonesia. \\ ${ }^{3}$ Departments of Biology, Faculty of Mathematics and Natural Sciences, \\ Universitas Brawijaya, Indonesia \\ *corresponding author: agus@sith.itb.ac.id
}

Received: May 24, 2021. Revised: November 15, 2021. Accepted: December 7, 2021. Published: January 3, 2022.

\begin{abstract}
Crocidolomia pavonana Fabr. (Lepidoptera: Crambidae) is a major pest on various cabbage crops in Indonesia. Various insecticides have been used to control this insect pest including several entomopathogenic fungi, and this cabbage caterpillar has become resistant to various insecticides. In order to develop insecticides from entomopathogenic fungi, species or varieties from natural area such as forest are needed. A bioassays of Cordyceps sp. and Beauveria bassiana has been carried out in the laboratory. Inoculum of Cordyceps sp. obtained from the Dipterocarpaceae forest in South Kalimantan, Indonesia recovered from dead ants by the mycelium of Cordyceps sp. Four concentration of Cordyceps sp. and Beauveria bassiana inoculum and tween ${ }^{80}$ as a control were tested against $3^{\text {rd }}$ instar larvae of $C$. pavonana with five replications. Field efficacy trial was carried out in a screen house $\left(8 \times 12 \mathrm{M}^{2}\right.$ ) using Chinese cabbage plants (Brassica juncea) aged 28 days after sowing, with a spacing of $0.4 \mathrm{M}$ between rows. Three formulation of Cordyceps sp. and tween $^{80}$ as a control were used with 6 replications. The result of the bioassays in the laboratory showed that Cordyceps sp. with concentration of $1 \times 10^{7}$ conidia $\mathrm{mL}^{-1}$ was able to give $100 \%$ mortality od $C$. pavonana larvae, while $B$. bassiana with the same concentration caused morality of $C$. pavonana larvae of $98.33 \%$, although statistically not significantly different. The results of probit analysis also showed that $\mathrm{LC}_{90}$ Cordyceps sp. against cabbage caterpillar larvae was $1.57 \times 10^{6}$ conidia $\mathrm{mL}^{-1}$, while $B$. bassiana required a concentration of $2.6 \times 10^{6}$ conidia $\mathrm{mL}^{-1}$ to reach the $\mathrm{LC}_{90}$ value. The results of filed trial showed that the formulation of Cordyceps sp. $1 \times 107$ conidia $\mathrm{mL}^{-1}$ using palm oil cooking oil was able to give an average mortality of $86.7 \%$, and significantly higher $(P<0.05)$ than the other treatment. The results of this study indicate that the inoculum of Cordyceps sp. from
\end{abstract}

Dipterocarpaceae forest is very promising to be developed as an insecticide to control $C$. pavonana in cabbage

Keywords-Entomopathogenic fungi, Crocidolomia pavonana, Beauveria bassiana, Cordyceps sp.

\section{INTRODUCTION}

The large cabbage-heart caterpillar, Crocidolomia pavonana Fabricius (Lepidoptera: Crambidae), is an insect pest of cabbage plants in many countries of Africa, the Pacific and Asia, including in Indonesia [1-3]. C. pavonana often attacks cabbage plants grown in areas hot, humid, and at the altitude of more than $600 \mathrm{M}$ above sea level [4]. The early instar larvae od $C$. pavonana will live on the underside of the leaves, the larger ones will attack all parts of the cabbage plant $[2,4]$. The cabbage caterpillar populations often cause economic losses.

Synthetic insecticides are often used to control $C$. pavonana. In Indonesia, cabbage farmers can apply synthetic insecticides 2 to 3 time in 1 week [4].The continuous and inappropriate use of synthetic insecticides can lead environmental pollution, the occurrence of insecticides resistance, the destruction of natural enemies, disruption of human health, and excess chemical residues in crops, which can also affect consumers to obtain organic product [2-5].

Pests control efforts can be carried out with more environmentally friendly pesticides such as using botanical and microbial insecticides. Most of the studies that have been conducted have tested the effectiveness of botanical insecticides [4, 6-8]. Another alternative in controlling insect pests is the use of microbes as pest control agents. Various types of entomopathogens as insect pest control have been developed. Several isolates of entomopathogenic fungi have been studied and developed, such as Paecilomyces sp., B. 
bassiana, Verticillium sp., Spicaria sp. and Metharhizium anisopliae [9-11]. A study on molecular identification showed that seven genera of entomopathogenic fungi, namely Beauveria, Clonostachys, Cordyceps, Fusarium, Metarhizium, Penicillium, and Purpureocillium, had very high virulence [12]. Furthermore, the screening results from isolates of the genus Beauveria, and Metarhizium had high pathogenicity against Spodoptera litura [12]. The results of another study showed that isolates of Beauveria bassiana, Isaria fumosorosea, Isaria sinclairii, Lecanicillium muscarium, Metarhizium rileyi, and at a concentration of $1 \times 10^{7}$ conidia $\mathrm{mL}^{-1}$ were very effective in controlling the larvae of Plutela xylostella [11]. Application of entomopathogenic fungi for insect control must pay attention to management cost, such as the results of applying mathematical models in control of Bemisia tabaci, an insect that carries yellow viral disease of red chili using the entomopathogenic fungi, Verticillium lecanii, is only requires time for 15 days and a dose of $90 \%$ of the recommended dose [13].

Research on the effect of entomopathogenic fungi to control $C$. pavonana has not been widely carried out, although there have been several research results on the effect of $M$. anisopliase and B. bassiana on C. pavonana [14,15]. Study on the effect of Cordyceps sp. (especially those from natural forests) against $C$. pavonana larvae has never been done. Therefore, the objective of this study was to evaluate the potential of Cordyceps sp. from the Dipterocarpaceae forest in an effort to control C. pavonana in Chinese cabbage, and ultimately reduce the use of synthetic insecticides.

\section{II.MATERIALS AND METHODS}

\section{A. Fungal Culture.}

Cordyceps sp. were isolated from the dead ants isolated from the forest of Dipterocarpaceae in South Kalimantan. B. bassiana were reisolated from Laboratory of Microbiology Life Sciences Center, Institut Teknologi Bandung. Cordyceps sp. was isolated and re-cultured from mycelium collected on dead ants covered with fungi from Dipterocarp forest in South Kalimantan, Indonesia. Then identified and maintained using potato dextrose agar (PDA) media. B. bassiana was cultured using PDA media, and both fungi were maintained at room temperature. The 9-days-old fungal conidia from PDA media were scraped using a sterile scalpel from the plate surface, then suspended in distilled water containing $0.05 \%$ tween ${ }^{80}$. Conidia concentration of both entomopathogenic fungi were calculated using a Neubauer haemocytometer, and serial dilutions were carried out from $1 \times 10^{7}$ to $1 \times 10^{4}$ conidia $\mathrm{mL}^{-1}$.

C. pavonana was reared in the laboratory. The larvae were fed with Chinese cabbage (Brassica juncea) leaf which were planted in a screen house $\left(8 \times 12 \mathrm{M}^{2}\right)$ and without insecticides treatment. Adult insect were kept in gauze cages $(0.7 \times 0.6 \mathrm{x}$ $1.0 \mathrm{M}^{2}$ ), polybags containing Chinese cabbage were placed in the cage, $10 \%$ honey diluted with distilled water was used as adult insect feed [2-4]. Third instar larvae od C. pavonana were used for bioassays in the laboratory and field efficacy tests.

\section{B. Dosage-Mortality Bioassay.}

Twenty $3^{\text {rd }}$ instar larvae of $C$. pavonana were transformed to each 5 sets of Chinese cabbage leaf $\left(120 \mathrm{Cm}^{2}\right.$ per leaf $)$. The leaf stalks were wrapped in wet cotton with by aluminium foil cover, this method can keep the cabbage leaves fresh for up to 5-7 days. The two entomopathogenic fungi with concentration of $1 \times 10^{4}, 1 \times 10^{5}, 1 \times 10^{6}, 1 \times 10^{7}$ conidia $\mathrm{mL}^{-1}$, and $0.05 \%$ tween $^{80}$ as a control were sprayed on cabbages leaves using a hand sprayer (volume $1 \mathrm{~L}$ ). Each treatment was repeated 5 times and every treatment were also sprayed on PDA plate using bacteriological agar $\left(\right.$ Bacto $\left.^{\circledR}\right)$. After 24-96 hours, germinated conidia were counted under the microscope [10$12,14]$.

Bioassays were carried out in the same laboratory as insect rearing. Fifteen to twenty minutes after treatment, all cabbages leaves were transferred into cylindrical plastic bottles (height $11 \mathrm{Cm} \times \varnothing 12 \mathrm{Cm}$ ) and covered with gauze.

Bioassays were conducted in the same laboratory as insect rearing. Ten to fifteen minutes after inoculation with hand sprayer, each treated leaf was placed in a sylindrical plastic bottle (Ø $12 \mathrm{~cm}$ and $11 \mathrm{~cm}$ in height). The numer of dead larvae was counted up to 6 days. Probit analysis to determine the $\mathrm{LC}_{50}$ and $\mathrm{LT}_{50}$ values were carried out using the Polo PC program $[11,15]$.

\section{Field Trial.}

Twenty eight days Chinese cabbage (insecticides free) in polybag (height $14 \mathrm{Cm} \times \varnothing 20 \mathrm{Cm}$ ) was placed in a screen house with the distance of $0.4 \times 0.45 \mathrm{M}$. The treatment in the field efficacy test used Cordyceps sp. with concentration of $1 \mathrm{x}$ $10^{7}$ conidia $\mathrm{mL}^{-1}$, and made into a formulation of PDA, oil palm cooking oil (40\% mono-unsaturated; Kunci Mas ${ }^{\circledR}$ ), and rice flour. The formulation of Cordyceps sp. with palm oil cooking oil was made from $0.03 \mathrm{~g}$ of 9-days old conidia of Cordyceps sp. cultured mixed with $30 \mathrm{~mL}$ of Kunci Mas ${ }^{\circledR}$. The same amount and age of Cordyceps sp. conidia were mixed with $30 \mathrm{mg}$ of rice flour, then suspended with $0.01 \%$ tween $^{80}$ in sterile distilled water, and this tween ${ }^{80}$ solution was used as a control $[9,-12]$.

All formulation solution were shaken vigorously, then the conidia solution filtered using cotton gauze, so there was a separation between the conidia liquid and the solid phase. Conidia solution from each treatment was sprayed as much as $10 \mathrm{~mL}$ with a hand sprayer (volume $1 \mathrm{~L}$ ) for each cabbage plant that had been infested with ten $3^{\text {rd }}$ instar larvae of $C$. pavonana. Each treatment was repeated 6 times, and spraying was carried out in the morning between 07.00 09.00. Observation of dead larvae were carried out after 24 hours, and recorded for 6 days to calculated the percentage of cumulative mortality $[12,14]$. To prove that the dead $C$. pavonana larvae were caused by the fungus Cordyceps sp, the dead larvae were sterilized with $0.5 \%$ sodium hypochlorite for 5 minutes, then rinsed using sterile distilled water and inoculated on PDA media. 


\section{RESULTS AND DISCUSSION}

\section{A. Bioassays}

The results of the study showed that all concentration of enromopathogenic fungi used has caused the death of $3^{\text {rd }}$ instar larvae of $C$. pavonana (Table 1), with the higher concentration of treatment used, the percentage of $C$. pavonana larvae mortality increased. From laboratory bioassays, the Cordyceps sp. concentration of $1 \times 10^{6}$ conidia $\mathrm{mL}^{-1}$ has caused more than $75 \%$ mortality, and mortality of the $C$. pavonana larvae has reached $100 \%$ mortality with the Cordyceps sp. concentration of $1 \times 10^{7}$ conidia $\mathrm{mL}^{-1}$.

Table 1. Mean percentage of mortality on third instar larvae of C. pavonana after 4 days exposure to Cordyceps sp.and B. bassiana.

Dosage

(conidia $\mathrm{mL}^{-1}$ )

$\begin{array}{lcc}10^{4} & 35.33 \pm 1.67^{\mathrm{a}} & 38.33 \pm 1.67^{\mathrm{a}} \\ 10^{5} & 51.67 \pm 3.33^{\mathrm{b}} & 58.33 \pm 4.41^{\mathrm{c}} \\ 10^{6} & 78.33 \pm 3.33^{\mathrm{d}} & 83.33 \pm 1.67^{\mathrm{e}} \\ 10^{7} & 100 \pm 0.00^{\mathrm{f}} & 98.33 \pm 1.67 \mathrm{f}^{\mathrm{g}}\end{array}$

Cordyceps sp.

B. bassiana

The results of probit analysis showed that the LC90 of Cordyceps sp. was estimated at $1.57 \times 10^{5}$ conidia $\mathrm{mL}-1$, and statistically, it was lower than LC90 of B. bassiana $\left(2.6 \times 10^{6}\right.$ conidia $\mathrm{mL1}$ ) (Table 2). The calculation of probit analysis predicted that between log-dosage and probit mortality has significant correlation $(\mathrm{P}<0.05)$ for the two type of entomopathogenic fungi.

Table 2. Effect of Cordyceps sp. and B. bassiana on third instar larvae of C. Pavonana

\begin{tabular}{ccc}
\hline Fungi & $\mathrm{LC}_{50}$ conidia $\mathrm{mL}^{-1}$ & $\mathrm{LC}_{90}$ conidia $\mathrm{mL}^{-1}$ \\
\hline Cordyceps $\mathrm{sp}$. & $4.26 \times 10^{4}$ & $1.57 \times 10^{6}$ \\
B. bassiana & $1.02 \times 10^{5}$ & $2.6 \times 10^{6}$ \\
\hline
\end{tabular}

From the observation of the lethal concentration test, it has been shown that many $C$. pavonana larvae stay away from feed on the second day after treatment, this is because both entomopathogenic fungi started to produce a lot of spores on the surface of the larvae. The results of this test also showed that there was a decrease in pathogenicity over time. In line with the increasing concentration of the fungi, the time needed to control C. pavonana larvae was getting faster (Table 3).

Table 3. Median lethal time of third instar larvae of $C$. pavonana after 4 days exposure to Cordyceps sp.and B. bassiana.

\begin{tabular}{ccccc}
\hline $\begin{array}{c}\text { Dosage } \\
\left(\text { conidia } \mathrm{mL}^{-1}\right)\end{array}$ & \multicolumn{2}{c}{ Cordyceps sp. } & \multicolumn{2}{c}{ B. bassiana } \\
& $\mathrm{LT}_{90}$ & $\mathrm{LT}_{50}$ & $\mathrm{LT}_{90}$ & $\mathrm{LT}_{50}$ \\
& (days) & (days) & (days) & (days) \\
\hline $10^{4}$ & 11.78 & 4.71 & 9.96 & 4.97 \\
$10^{5}$ & 7.66 & 3.68 & 6.54 & 3.93 \\
$10^{6}$ & 5.06 & 2.80 & 4.60 & 3.01 \\
$10^{7}$ & 3.57 & 2.40 & 3.76 & 2.50 \\
\hline
\end{tabular}

\section{B. Field Trial with Cordyceps sp.}

The results of the efficacy test of the formulation of Cordyceps sp. showed that the formulation using cooking oil from palm oil resulted in average mortality of $86.7 \%$ (Table 4 ), and was significantly different from the formulation using rice flour and control, but slightly different from the formulation using only PDA (74.3\%).

The high mortality of the formulation using cooking oil from palm oil was probably due to the increased adhesion of the solution to cabbage leaves compared to the formulation that only used PDA and rice flour. The relative humidity at the study site in the city of Bandung, which is located at an altitude of $800 \mathrm{M}$ above sea level, and surrounded by mountains, may also increase the pathogenicity of the fungi.

Table 4. Mean percentage of mortality amongst the treatments of Cordyceps sp. on third instar larvae of Crocidolomia pavonana.

\begin{tabular}{lc}
\hline Treatments $^{\mathrm{a}}$ & Mean $\%$ mortality \\
\hline 1. Conidia from PDA in oil palm & $86.7 \mathrm{a}$ \\
cooking oil & \\
2. Conidia from PDA only & $74.3 \mathrm{ab}$ \\
3. Conidia from rice flour & $71.0 \mathrm{~b}$ \\
4. Control $\left(\right.$ Tween $\left.^{80}\right)$ & $12.5 \mathrm{c}$ \\
LSD & 9.08 \\
MSE & 305.5 \\
CV & 17.87
\end{tabular}

A sterile aqueous Tween ${ }^{80}(0.05 \%)$ was the spray carrier.

Mortality data was transformed by X root arc sine.

The same letter in the mean mortality are not significantly different (2-way Anova and LSD, $\mathrm{P}=0.05$ ).

Discussion

Beauveria bassiana, Nomuraea, Metarhizium, Paecilomyces, and Fusarium are some fungal genera that have high pathogenicity against insect pest species [17-22]. Bioassay of $B$. bassiana and Cordyceps sp. on Sitophilus oryzae showed that the death of $S$. oryzae was caused by 
sporulation of these fungi on the insect body surface [18], the result of this study also showed the same symptoms. Paecilomyces fumosoroseus (teleomorph: Cordyceps sp.) has high pathogenicity against Plutella xylostella (Diamondback moth) larvae [19], as well as egg and larvae of C. Pavonana [20]. $P$. fumosoroseus can caused ca. 2.5 times than $B$. Bassiana against $P$. xylostella larvae. The sporulation of $P$. fumosoroseus (teleomorph: Cordyceps sp.) and B. Bassiana also occured on the surface of dead $P$. xylostella larvae, as well as the case of this study, however, the body of $P$. xylostella larvae infected by $M$. anisopliae var. majus was not completely covered with fungal mycelium [22]. Several different results occurred in the pathogenicity of entomopathogenic fungi other than Cordyceps and $B$. bassianaon $C$. pavonana eggs, although, the virulence of these fungi remained high on C. pavonana larvae [20].

The use of the fungus $M$. anisopliae has the potential to control $P$. xylostella and $C$. binotalis ( $C$. pavonana), Concentration of $200 \mathrm{~g} / \mathrm{L}$ water showed the highest net weight (1,583 g/crop) [14]. Meanwhile, the best bioactivity of $M$. anisopliae was found in the $10^{\text {th }}$ week after storage, namely in the pellet formulation with a concentration of $10^{7}$ conidia $\mathrm{mL}^{-1}$.

The results of the field efficacy test indicated that $M$. anisopliae formula can still live in the field, beside its presence in the field, is still able to control $C$. pavonana larvae until the $4^{\text {th }}$ day after application, both pellet formulations and flour formulations [14]. The results of bioassays of the suspension of $M$. anisopliase in tween ${ }^{80}$ showed that from the day $3, M$. anisopliase could produces mycotoxins, the amount of mycotoxins production was directly proportional to the growth period of the fungi, and optimal production occurs on day 7, these mycotoxins include myroridins, destruxins, hydroxyfungerins $\mathrm{A}$ dan $\mathrm{B}$, metacytophilin, fusarin $\mathrm{C}$, cytochalasins C and D [23]. Destruxin known to be the most abundant most abundant mycotoxins produced by Metharhizium, however, its virulence varies depend on the variety of species Metharhizium [24], Until now, destruxin, a mycotoxins from $M$. anisopliase is known to have insecticidal activity, destruxin can reduce insect immunity, however, its mode of action is not widely known [25]. The results of other study indicated that destruxin A can bind to transmembrane protein 214 and the transport protein (BmSEC23) from the larvae of Bombyx mori, and this binding has been predicted to increase the mortality of B. mori [26].

The study of the virulence level of 41 entomopathogenic isolates from Thailand against western flower thrips (Frankliniella occidentalis), showed that there were 14 isolates that were virulent. Among these isolates, two isolates of $B$. Bassiana had an LC50 level below $6.61 \times 10^{4}$, while the isolate Cordyceps sp. had an LC50 of $4.47 \times 10^{5}$ [27]. Our results showed the opposite results. LC50 level Cordyceps sp. against $C$. pavonana was lower than $B$. bassiana, meaning that Cordyceps sp. was more virulent than B. Bassiana. Therefore, the results of the field test are important to evaluate the success of the application. Another study showed that the results of mathematical modeling of infected red chili plant populations (in the vegetative and generative phases) decreased due to the application of $V$. lecanii, which drastically reduced the population of B. tabaci of the yellow virus [13].

Several types of oil may help spread the conidia of the fungi on hydrophobic surface such as on insect cuticles [23,24].This results of this research may also the theory of conidia dispersal with the help of certain oils on the body surface of insect larvae. Research on mass production of spore suspensions of $B$. bassiana and P. fumosoroseus in Malaysia showed that the two fungi with concentration of $1 \times 10^{8}$ spores $/ \mathrm{mL}$, equivalent to $3.75 \times 10^{13}$ spores/ha. could reduce population of $P$. xylostella larvae [21]. The results also showed that the rice and coconut water formulation were suitable media for the growth and sporulation of $B$. bassiana and $P$. fumosoroseus. The concentration of entomopathogenic fungi should be considered in the cost of pest control, such as the results of research on controlling B. tabaci in red chilli plants [13]. The results of Cordyceps sp. formulation using rice flour on $C$. pavonana larvae in this research, are in line with the results of research [21], where the rice flour formulation can produce $C$. pavonana mortality of $71 \%$. However, further effort are still needed to develop the management strategies for $C$. pavonana in Indonesia.

\section{CONCLUSION}

The results of this present study suggest entomopathogenic fungi, Cordyceps sp. originating from Dipterocarpaceae forest in Central Kalimantan Indonesia was able to provide better mortality against $C$. pavonana larvae than $B$. bassiana. Field efficacy test of Cordyceps sp. suspension with a mixture of cooking oil from oil palm offers promising results for further development in the control strategy of the large cabbage-heart caterpillar, C. pavonana.

\section{REFERENCES}

[1] A. Uelese, P. M. Ridland, R. Stouthamer, Y. He, G. Ang, M. P. Zalucki, M. J. Furlong, "Trichogramma chilonis Ishii: A potential biological control agent of Crocidolomia pavonana in Samoa," Biol Control, vol. 73, pp. 31-38, 2014.

[2] E. C Lina, Dadang, S. Manuwoto, G. Syahbirin, D. Prijono, "Synergistic action of mixed extracts of Brucea javanica (Simaroubaceae),

Piper aduncum (Piperaceae), and Tephrosia vogelii (Leguminosae) against cabbage head caterpillar Crocidolomia pavonana," J Biopest 6(1), pp. 77-83, 2013.

[3] A. M. V Javier, A. Mia, V. O. Ocampo, F. A. Ceballo, P. A. Javier, "Insecticidal Activity of Crude Ethanolic Extracts of Five Philippine Plants against Cabbage Worm, Crocidolomia pavonana Fabricius (Lepidoptera: Crambidae)," Philipp J Sci, vol. 147, pp. 513-521, 2018.

[4] S. Sastrosiswojo, W. Setiawati. Hama-hama tanaman kubis dan cara pengendaliannya. in. A.H. Permadi, S. Sastrosiswojo (eds). Kubis. pp 39-50. Balai Penelitian Hortikultura Lembang - Bandung. 1993.

[5] R. Bommarco, F. Miranda, H. Bylund, C. Bjorkman, "Insecticides suppress natural enemies and 
increase pest damage in cabbage. J Econ. Entomol, vol. 104(3), pp. 782-791. 2011.

[6] N. Nailufar, D. Prijono, "Synergistic Activity Of Piper Aduncum Fruit and Tephrosia vogelii Leaf Extracts Against the Cabbage Head Caterpillar, Crocidolomia pavonana," J. ISSAAS, vol. 23(1), pp. 102-110, 2017.

[7] E. Syahputra, K. Hernowo, Riko, "Effect of Castanopsis megacarpa Extract on Mortality, Longevity Development and Feeding of Crocidolomia pavonana Larvae," AJAS, vol. 41(3), pp. 537-543, 2019.

[8] D. Prijono, R. D. R. Wulan, Ferdi, N. A. Saryanah, "Insecticidal activity of the extracts of Piper retrofractum fruit and Tephrosia vogelii leaf and their mixtures against Crocidolomia pavonana," Cropsaver, 3(2): 68 - 75. 2020.

[9] Y. Prayogo, W. Tengkano, dan Marwoto, "Prospek Cendawan Entomopatogen Metarhizium anisopliae untuk Mengendalikan Ulat Grayak Spodoptera litura pada Kedelai," Jurnal Litbang Pertanian, vol 24(1), pp.19-26, 2005.

[10] A. Hasyim, W. Setiawati, R. Murtiningsih, Y. Hilam and E. Sofiari, "Potential of entomopathogenic fungi and essential oil from aromatic plants in managing two lepidopterous cabbage pests in Indonesia. Proceedings The 6th Inter. Workshop on Management of the Diamondback Moth and Other Crucifer Insect Pest, AVRDC, 77-86. 2011.

[11] R. T. Duarte, K. C. Gonvalces, D. J. L. Espinosa, L. F. Moreira, S. A. De Bortoli, R. A. Humber and R. A. Polanczyk, "Potential of Entomopathogenic Fungi as Biological Control Agents of Diamondback Moth (Lepidoptera: Plutellidae) and Compatibility with Chemical Insecticides," J Econ Entomol, 109 (5), pp. 594-601, 2016.

[12] J-C. Chang, S-S. Wu, Y-C. Liu, Y-H Yang, Y-F. Tsai, Y-H. Li, C-T. Tseng, L-C Tang, and Y-S. Nai. "Construction and Selection of an Entomopathogenic Fungal Library From Soil Samples for Controlling Spodoptera litura." Front. Sustain. Food Syst., 5: Article 596316, 1-14, 2021

[13] R. Amelia, N. Anggriani, A.K. Supriatna, "Optimal Control Model of Verticillium lecanii Application in the Spread of Yellow Red Chili Virus". WSEAS Transactions on Mathematics 8: $351-358$

[14] T. Sunardi, Nadrawati. "Efektivitas Cendawan Metarrhizium anisopliae Sorokin terhadap Plutella xylostella Curt dan Crocidolomia binotalis Zeller," Jurnal Akta Agrosia, vol. 11(2), pp. 157-161, 2008.

[15] Nuraida, A. Lubis, "Pengaruh formulasi dan lama penyimpanan pada viabilitas, bioaktivitas dan persistensi cendawan Metarhizium anisopliae terhadap Crocidolomia pavonana Fabricius," J. HPT Tropika, vl. 16, pp. 196-201, 2016

[16] N. T. Sirajuddin and T. Anggraeni, "The Effect of Leaf Biopesticide Mirabilis jalapa and Entomopathogenic Fungi (Beauveria bassiana) Combinations to Some Physiological Characters and Histology", AIP Conference Proceedings 1589, pp. 308, 2014.

[17] H. Liu, M. Skinner, B. L. Parker, and M. Brownbridge,8"Pathogenicity of Beauveria bassiana, Metarhizium anisopliae (Deuteromycotina: Hyphomycetes), and other Entomopathogenic Fungi Against Lygus lineolaris (Hemiptera: Miridae)," J. Econ. Entomol. 95(4): 675-681, 2002.

[18] H. F. Sari,. Uji Efikasi Fungi Entomopatogen Beauveria bassiana (Balsamo) dan Cordyceps sp. terhadap Sitophilus oryzae (L.) (Coleoptera: Curculionide) dalam Kondisi Laboratorium. Skripsi Sarjana Biologi. Institut Teknologi Bandung, 2009

[19] S. Chaterina, Potensi Jamur Entomopatogenik Paecilomyces fumosoroseus (Moniliales : Moniliaceae) Sebagai Agen Alternatif
Pengendali Plutella xylostella L. (Lepidoptera: Plutellidae). Skripsi Sarjana Biologi. Institut Teknologi Bandung, 2001.

[20] A. Hasyim, Nuraida, dan Trizelia, " Patogenisitas Jamur Entomopatogen terhadap Stadia Telur dan Larva Hama Kubis Crocidolomia pavonana Fabricius," J. Hort, 19(3), pp. 334-343, 2009.

[21] Y.B. Ibrahim, and W. Low, Potential of mass-production and field efficacy of isolates of the entomopathogenic fungi Beauveria bassiana and Paecilomyces fumosoroseus against Plutella xylostella. International Journal of Pest Management 39: 288-292, 1993.

[22] N. Hashim, Y.B. Ibrahim, M. Vanhake, "Relative virulence of entomopathogenic fungi Paecilomyces fumosoroseus and Metarhizium anisopliae var major on Plutella xylostella (Lepidoptera: Yponomeutidae). In Entomology in Malaysia Beyond 2000: Exploration, Imploration and Digitisation, ed. S.T.S. Hassan et al., p.114-116. Entomological Society of Malaysia. 1999.

[23] Melanie, M. Miranti, H. Kasmara, S. Hazar and A. Martina, "Insecticidal activities of crude extact of Metarhizium anisopliae and conida suspension against Crocidolomia pavonana fabricius," IOP Conference Series: Earth and Environmental Science. 166, 012017. 2018.

[24] Morallo R B and Navasero W R, "Biology of Crocidolomia pavonana (F.) and population inventions against this recurrent pest of crucifers in the Philippines," Philippines Entomologist 17 141-168, 2003.

[25] M. I. Bogus, A. K. Vronska, A. Kaczmarek, M. BogusSobocinska, "In vitro screening of 65 mycotoxins for insecticidal potential," J. of Fungi, 7(6), 460: 1-7. 2021

[26] F. Yin, M. Xiao, A. Berestetskiy, Q. Hu, "The Metarhizium anisopliae Toxin, Destruxin A, Interacts with the SEC23A and TEME214 Proteins of Bombyx mori.J. of Fungi, 7, 460: 1-7, 2021.

[27] C. Sengonca, M. Thungrabeab and P. Blaeser, "Potential of different isolates of entomopathogenic fungi from Thailand as biological control agents against western flower thrips, Frankliniella occidentalis (Pergande) (Thysanoptera: Thripidae)," J. of Plant Diseases and Protection, 113(2): 74-80, 2006.

\section{Creative Commons Attribution License 4.0 (Attribution 4.0 International, CC BY 4.0)}

This article is published under the terms of the Creative Commons Attribution License 4.0 https://creativecommons.org/licenses/by/4.0/deed.en_US 